\title{
Preventing Psychological Wear in Healthy Organizations. Research in the State of Hidalgo, Mexico
}

\author{
M. Angeles Carrion Garcia \\ $\mathrm{PhD}$ in Psychology Summa cum Laude \\ President of the Association of Experts in Applied Psychology - AEPA. \\ Mollet del Vallés, Barcelona, Spain \\ Consultant at Universitat Oberta de Catalunya, Barcelona, Spain \\ Tirso Javier Hernandez Gracia
}

$\mathrm{PhD}$ in Administrative Sciences, Institute for Economic and Administrative

Sciences. Universidad Autónoma del Estado de Hidalgo, Mexico

\section{Francisco Lopez Baron}

Doctorate from Universidad Autónoma de Barcelona and in Occupational

Health Sciences from Universidad de Guadalajara, Mexico

Institut Universitari de Ciència i Tecnologia - IUCT. Universitat de Vic.

Mollet del Valles, Barcelona, Spain

\section{Alejandra Corichi Garcia}

Bachelor Degree in Administration and a Master's in Business

Administration, Institute for Economic and Administrative Sciences.

Universidad Autónoma del Estado de Hidalgo, Mexico

Abstract

Materials and methods: Non-experimental, cross-sectional quantitative study of 188 employees in different business sectors, State of Hidalgo, Mexico. Instrument: a battery for the study of psychosocial work conditions "CTCPS-MAC". A bivariate and multivariable logistic regression analysis was made with IBM SPSS Statistics 21 of psychological wear and psychosocial factors. Results: Work Context $(\mathrm{p}=0.000 \operatorname{Exp}(\mathrm{B})=5.565)$ infers a greater risk of cognitive-emotional psychological wear. Behavioral level: individual factors $(\mathrm{p}=0.000 \operatorname{Exp}(\mathrm{B})=8.531)$ and work context $(p=0.000 \operatorname{Exp}(B)=4.759)$. Physiological level: work content $(p=0.000 \operatorname{Exp}$ $(\mathrm{B})=8.765)$ Conclusions: Probability of psychological wear at the behavioral level: $94.87 \%$ in employees with a negative perception of their personal traits and the work/family interrelation. Physiological level: $97.70 \%$ for employees in the morning or morning/afternoon shift, good perception of 
individual factors regarding their personal traits and psychological risk buffers and a bad perception of company characteristics, equipment and physical agents.

Keywords: Evaluation, Healthy Organizations, Occupational Health, Psychological wear, Work Conditions

\section{Introduction}

Mental health management in companies and organizations is increasingly important. As mentioned by Knifton et al. (2011), the mental health and wellbeing of employees are crucial to the success of organizations in the XXI century. Over the past few decades, the importance of clinical psychology and health and applied ergonomics to prevent occupational hazards has increased (Carrion-Garcia, Lopez-Baron and Gutierrez-Strauss, 2015) and beyond; i.e., towards a positivist approach to healthy, sustainable companies and organizations.

The World Health Organization (WHO) defines positive mental health as " a state of well-being in which every individual realizes his or her own potential, can cope with the normal stresses of life, can work productively and fruitfully, and is able to make a contribution to her or his community" (2013). Being able to participate in organizations in this regard will depend on regulatory requirements, business culture and policies, social pressure and the level of quality of life in the country where he or she is located (Lopez-Baron and Martinez-Alcantara, 2008). Furthermore, the mental health program at the company should be managed within the framework of a Healthy Business Program that is adapted to its needs, to the organization's culture, its size, and the needs of its personnel and management (Carrion-Garcia and Lopez Baron, 2009).

A search was made of the Virtual Health Library (VHL) portal that includes the Cochrane and Cochrane Plus, MEDLINE, LILACS, IBEAS libraries among other international databases. The choice of "title, abstract, topic" indicates that 474,999 titles have been published on "stress", 14,416 on "occupation stress", 2,845 on "healthy organization", 105 on "healthy company”, 3,370 on "psychological wear" and 2,206 on "mental wear”.

A search was also made on the PsycNET of the American Psychological Association (APA) for articles published in magazines with peer review, with the result that over the past one hundred years (from 1915 to April of 2015) 926 articles have been published on "occupational stress", 156 on "healthy company", 73 on "healthy organization" and 45 on "psychological wear".

Three articles were found in the first search combining the terms "psychological wear" and "healthy organization" but the areas of study did 
not deal with the contents taken up in this paper, and no article with this condition appeared during the second search, focused on the field of psychology.

The fact that we found 10,952 results with "burnout" in the first search caught our attention; it is a little less than the number found for "occupational stress" while the second search turned up 421, less than half the number of articles found on "occupational stress" (926). This last fact can be interpreted as a close approximation to the psychosocial reality of organizations. As mentioned by Lopez-Baron and Carrion-Garcia (2009), the same happens with the topic of "mobbing" that has more results than "stress", a fact that questions the importance being given to it. All this reflects the need to consider concrete reliable studies as well as to prioritize the topic with the importance it deserves in relation with other psychosocial topics at the workplace.

Safety and health at work traditionally maintain a line of activity focused only on occupational injuries and disease; i.e., from a negative approach inspired by a medical model of protection (Salanova, 2008) that later gradually introduced specific health promotion programs. Lately, based on the occupational-psychosocial reality, the organizational development model, a conceptualized applied perspective of healthy organization, has gradually been instituted with a systemic comprehensive long-term approach with individual (quality of life, development of competencies) and organizational (greater productivity) benefits, with the development of programs for this purpose.

The Association of Experts in Applied Psychosociology (AEPA), an organization that acts as a bridge of knowledge between companies and academia, has developed a methodology for psychosocial intervention over the past decade that is presented with a degree of expertise sophistication as mentioned by researchers (Pando and Salazar, 2007; Holten, Gensby and Nielsen, 2008), and by institutions both academic and those specializing in preventing occupational hazards (National Occupational Safety and Hygiene Institute, INSHT, 2008). Psychosocial diagnostic instruments have also been created under its wing, including the CTCPS-MAC battery used in the research for this paper on psychosocial working conditions (Carrion-Garcia, 2014) as well as in the implementation and maintenance of a program for healthy sustainable companies and organizations (Carrion-Garcia, 2010).

The Royal Spanish Academy Dictionary defines "wear" as the "action and effect of wearing out or being worn out" (2001a), and gives as the first definition of "wear out" slowly taking or consuming part of something due to use or friction" while the fourth definition given is "to loss strength, vigor or power" (2001b). It defines "psychological” as an adjective "pertaining to or related to psychological functions and contents" (2001c). 
Carrion-Garcia (2014) considers psychological wear in her CTCPSMAC battery for the study of psychosocial working conditions, defined by physical, cognitive, emotional and behavioral symptomology that appears when faced with stressors such as exposure to different kinds of psychosocial occupational hazards that may lead to physical, psychological and social damage.

Research of psychological wear has focused on the consequences of burnout, among others, and underscore emotional factors (Moreno-Jimenez, Gonzalez and Garrosa, 2001; Mababu, 2012) to explore the disclosed association between burnout and cognitive functions (Deligkaris et al., 2014) as the organizational syndrome (Letelier, Navarrete and Farfan, 2014). Reviews have also been made, including occupational stress and burnout as related to differentiation, training and intervention (Rodriguez and De Rivas, 2011), for preventing burnout and occupational stress through engagement (Carrasco, De La Corte, Leon, 2010).

The burnout syndrome implies psychological wear but not all psychological wear is burnout (Gil-Monte, 2003). In this regard, INSHT in its questionnaire on psychosocial factors F-PSICO Version 3.1, evaluates "psychological demands "as one of the risk factors; that is, the cognitive and also emotional demands that must be coped with on the job (INSHT, 2014) but not their effects or consequences that are covered by the CTCPS-MAC battery for the study of psychosocial work conditions (Carrion-Garcia, 2014). The "psychological wear" dimension entails subjective health symptoms and alterations and the following psychological states: cognitiveemotional, behavioral and physiological responses.

In an investigation of patients affected by harmful psychosocial factors in the work environment (Carrion-Garcia, 2013), the results showed that $84.21 \%$ up to $100 \%$ of the cases studied manifested psychological symptoms. $100 \%$ of the cases showed anguish, anxiety, low state of mind and emotional lability. 92.11\% showed solitude/isolation, apathy, mistrust and insecurity/low self-esteem respectively. $89.47 \%$ had symptoms of demotivation and failing attention/memory. Sleep disorders (81.58\%) and breathing difficulties (73.68\%) were the most common physical symptoms.

Psychosocial factors are those that appear in interactions between conception, organization management model, work content, design and completion of tasks, environmental and social conditions as well as skills, needs, expectations, customs, culture and the workers' personal circumstances. These interactions may potentiate or affect the worker's wellbeing, quality of life and/or health as well as work performance (LopezBaron and Carrion-Garcia, 2006).

There are 10 different categories into which some psychosocial factors, those dealing with work context and those related to work content, 
may be classified. All of them have shown they may be dangerous under certain circumstances, stressful and harmful to health (Cox, Griffiths and Rial-Gonzalez, 2000).

Different causes occur to increase a person's vulnerability to the psychosocial risk factors they face at work; a negative perception of him or herself at the workplace and of his or her capacity to respond. Thus, subjective health symptoms and alterations develop and affect the person, alter his or her psychological state and his or her cognitive-emotional, behavioral and/or physiological response, triggering the appearance of psychological wear (Carrion-Garcia, 2014).

When a person maintains a perception in keeping with reality and handles positive health indicators, he or she is able to have greater protection and maintain proper behavior in coping with and resolving different psychosocial risks to which he or she is exposed to at work.

There are different definitions of a healthy work environment. The World Health Organization (2010) indicates that any definition thereof must meet the WHO definition that considers a state of complete physical, mental and social wellbeing and not just the absence of sickness. In this regard, the West Pacific Regional WHO Office defines a healthy work environment as "A place where everyone works together to achieve a joint vision of health and wellbeing for all employees and the community. This provides all its members..." "...physical, psychological, social and organizational conditions that protect and promote health and safety." "This allows" all "to have increasingly more control over their own health, to improve it and to be more energetic, positive and happy." (2010)

For Carrion-Garcia (2003): "Healthy organizations are those that from a position of optimal competent leadership have as a priority goal attaining a level of excellence in all areas of the company, taking into account organizational aspects such as individual, environment and social, and achieve the best level of quality, productivity and competence by promoting physical, mental and social health among the entire personnel."

In the overall management of healthy organizations, psychosocial factors, especially organizational ones, warrant special oversight given that they may trigger negative responses or maladjustment, tension and psychophysiological responses to stress (Moreno and Baez, 2010). One should take individual differences into account with regard to subjectivity and vulnerability that may be acted out. As Diaz (2011) says, not all workers are alike; while some of them may find a situation to be quite threatening, it may go unnoticed by others in the same situation.

Psychosocial work conditions affect physical, mental and social health and safety both positively and negatively (Rotenberg, 2004; Dejours, 2008; Londoño et al, 2010). Current advances aim at creating and 
maintaining companies and organizations healthy, permeation both in theoretical and practical psychology from the perspective of positive psychology where special emphasis is placed on the strength of people and their optimal performance, in an attempt to identify factors that protect workers' occupational and personal wellbeing, to explain why there are people and organizations that enjoy greater positive energy concerning work, and how they got that way (Blanch, Sahagun and Cervantes, 2010; Diez and Dolan, 2008); to stop focusing only on psychosocial diagnoses of individual or job design factors in their approach to work stressors, taking into account important elements such as work groups that can exert protective factors or the opposite as sources of traditional stress (Tucker et al, 2013). The latest trends in burnout studies, as mentioned by Carrasco, De la Corte and Leon (2010), have shifted to the theoretical opposite: “engagement”.

Different studies show that positive experiences, positive individual traits and positive organizations may improve quality of life and prevent pathologies. When a set of positive emotions are generated in the work environment among the people and the work they do, a state of wellbeing is attained, creating a protective factor against stress (Vazquez, 2006; Vera, 2006).

Different investigations have studied psychological wear in the psychosocial setting by means of a battery for studying psychosocial work conditions, "CTCPS-MAC”, in different business sectors (Carrion-Garcia, Lopez-Baron and Gutierrez-Strauss, 2015; Saldaña et al, 2014; CarrionGarcia, Gutierrez-Strauss and Lopez-Baron, 2015). The objective of this study is to identify the perceptions of psychological wear held by 188 workers in different business sectors in the State of Hidalgo, Mexico, by means of the effects such as subjective health symptoms and alterations and their association with the psychosocial factors present in their work environment.

\section{Materials and methods}

Non-experimental, cross-sectional (descriptive, correlational-causal) and quantitative design. A non-probabilistic sample of 188 workers from the workforce of different sectors, in companies with between 6 and 100 workers in the State of Hidalgo, Mexico, selected for convenience. As the inclusion criteria, companies with which the researchers and their institutions had been in touch with previously and that were registered in SIEM (the Mexican Business System) were taken into account. The kind of research is exploratory, descriptive, correlational and multivariate explanatory-causal. Limitation: The validity of the investigation is consolidated with repetition (Hernandez, Fernandez and Baptista, 2010). The data and results of the instruments were analyzed with the IBM SPSS Statistics 21 software. 
The “CTCPS-MAC” battery was applied, consisting of 75 items and grouping four dimensions (work context, work contents, individual factors and psychological wear) and 14 factors. It evaluates the perception held by the person answering it regarding psychosocial work conditions in his or her own work environment as well as individual factors and subjective health symptoms and alterations.

It was administered after obtaining their prior agreement and informed consent pursuant to the standards recommended for applying it. The battery is validated with Spanish and Latin American populations (Carrion-Garcia, 2014). Total confidence of the battery is optimal $(\alpha=$ 0.805 ) and the 14 factors explain 58,726 of the total variance. Nevertheless, (see table 1) the ratios for each of the dimensions are not too high.

Table 1. Cronbach Alfa Results

\begin{tabular}{ccccccc}
\hline Population & $\begin{array}{c}\text { Work } \\
\text { Context }\end{array}$ & $\begin{array}{c}\text { Work } \\
\text { Content }\end{array}$ & $\begin{array}{c}\text { Individual } \\
\text { Factors }\end{array}$ & $\begin{array}{c}\text { Psych. } \\
\text { Wear }\end{array}$ & Total & $\begin{array}{c}\text { Total } \\
\text { Workers }\end{array}$ \\
\hline Hidalgo S. & $\mathbf{0 . 5 8 6}$ & $\mathbf{0 . 5 4 5}$ & $\mathbf{0 . 5 2 5}$ & $\mathbf{0 . 6 6 6}$ & $\mathbf{0 . 8 0 5}$ & $\mathbf{1 8 8}$ \\
Spain & 0.879 & 0.857 & 0.765 & 0.884 & 0.942 & 190 \\
Colombia & 0.832 & 0.714 & 0.789 & 0.820 & 0.916 & 370 \\
Latin Amer. & 0.839 & 0.761 & 0.775 & 0.848 & 0.927 & 1.266 \\
\hline
\end{tabular}

Source: Results obtained from participants in different business sectors in the State of Hidalgo, México, 2014 and other research

Multivariate causal hypothesis (Hi): Negative perception of workrelated psychosocial factors (work context: organization culture and management, role in the organization, interrelation of work with family or social problems and interpersonal relations at work; work content: workload and pace, work environment, equipment and physical agents, and conception of the duties pertaining to the work position; individual factors: psychological risk buffers, company traits, and personal characteristics) trigger psychological wear through subjective health symptoms and alteration and psychological states (cognitive-emotional response, behavioral response, physiological response).

Cause (independent variables) - work-related psychosocial factors (negative perception)

Effect (dependent variables) - psychological wear (cognitiveemotional response, behavioral response, physiological response).

Specific objective: evaluate the relationship that exists between perceived psychological wear and work-related psychosocial factors. The study grouped the scores under Normal, Regular and Harmful as harmful factors indicating the need to carry out an action to correct the anomaly they reflect. On the other hand, the scores of Very Good and Good are taken as positive or protective factors not requiring corrective action. The primary objective is the application of acquired knowledge to optimize psychosocial 
factors related to work context, work content and individuals, and to promote workers' health by preventing psychological wear. To the extent in which the study and knowledge in this area progress, it will be possible to achieve healthy sustainable organizations.

The investigation began within an exploratory scope about psychological wear from perspectives other than those found in the literature where it is identified as burnout, to determine the work-related psychosocial factors that cause a higher risk for the psychological wear and thus be able to intervene in optimizing effective prevention. The descriptive enabled us to show the work-related psychosocial factors and the psychological wear accurately by measuring each of the variables as well as the description of the study's target population. The correlational scope allowed us to establish the relation between the variables and the causes to explain why psychological wear is produced, thus providing knowledge about the factors triggering it.

The associations were estimated by means of the Odds Ratio for the purpose of identifying to what extent psychosocial variables constitute a risk or protection factor in workers' psychological wear. The bivariate associations were explored by applying binary logistic regression for the bivariate analysis by analyzing the contingency tables for the purpose of a first approach to estimating the extent of association, the OR. Variables were classified according to the value of this measurement and its statistical significance in the Chi-square hypothesis, allowing us to test whether each of the psychosocial factors are conditioning factors bolstering the development of psychological wear in each of the possible responses. A "step by step" Multivariate Logistic Regression was performed to control possible confusion factors in the main evaluated list and to search among all possible explicative variables for those that explain the dependent variable better and more, without any of them being a linear combination of the rest. Psychosocial factors presumably associated with psychological wear were evaluated simultaneously as well as their cognitive-emotional, behavioral and physiological responses.

\section{Results}

In the sample of 188 workers, $44.7 \%$ were men and $55.3 \%$ women; the majority, 53.8\%, were married, $27.1 \%$ single, $7.4 \%$ living as a couple, 6.4\% divorced and 5.3\% others. 30.9\% were between 15 and 29 years old, 44.1\% between 30 and 39 and 25\% 40 or older. $32.4 \%$ had 2 children, $28.7 \%$ had no children, $18.1 \%$ had 1 child and $20.8 \%$ had 3 or more children. $35.7 \%$ had a bachelor's degree, 25\% a high school diploma, 16.5\% middle school education, $11.7 \%$ professional training, $7.4 \%$ a master's degree, $1.6 \%$ had 
studied diploma courses, $1.6 \%$ elementary school and $0.5 \%$ could read and write.

As for their employment information, 50\% belong to the Service Sector, $19.7 \%$ to the Education Sector, $11.7 \%$ to the Commerce Sector, $6.4 \%$ to the Food Sector, 4.8\% to Public Administration, 4.3\% to the Construction Sector and $3.1 \%$ to several other sectors. $72.9 \%$ had a full-time contract, $20.7 \%$ had an interim/temporary contract, $4.8 \%$ were self-employed, and 1.6\% other kinds. $45.7 \%$ worked the morning and afternoon schedule while $34.6 \%$ in the morning, $14.9 \%$ in the afternoon, $3.7 \%$ in shifts and $1.1 \%$ others.

Other employment data show that the greatest percentage, $17.6 \%$, held an administrative post, $14.9 \%$ were teachers, $11.2 \%$ salespeople, $9.6 \%$ assistants. $7.4 \%$ operators, $6.3 \%$ drivers, $4.3 \%$ held a managerial position, $3.7 \%$ were in middle management, $3.2 \%$ technicians, and $21.8 \%$ others. 43.1\% had 1 to 5 years seniority on the job, 22.9\% less than 1 year, $22.3 \%$ more than 5 and as many as 15 years, 9.6\% more than 15 and as many as 30 years seniority and $2.1 \%$ others. $34.5 \%$ had 1 to 5 years of seniority at the company, 34.1\% more than 5 and as many as 15 years, 17.6 less than one year, $12.2 \%$ more than 15 and as many as 30 years, and $1.6 \%$ others.

$84 \%$ had never taken a day of sick leave, $14.4 \%$ had taken 1 to 20 days, and $1.6 \%$ had 80 to 90 days of sick leave. $10.7 \%$ of them took it due to a common contingency, 2.1\% was for maternity leave, $2.1 \%$ for tendinitis, back pain, etc., and $1.1 \%$ due to surgery.

The overall results show us that Work context is Good or Very Good for $74.5 \%$ while it is harmful for $25.5 \%$. 20.7\% consider Work Content Good or Very Good while for $79.3 \%$ it needs improvement. Individual Factors are Good or Very Good for 68.6\% and negative for 31.4\%. 34.6\% did not claim Psychological wear while 65.4\% did.

The respective results of each of the factors (Table 2) show that in Dimension 1 - Work Context, the grouping of personnel having a good or very good perception of organization culture and management represent $57.4 \%$ while $42.6 \%$ stated the existence of harmful conditions requiring intervention. As for their role in the organization, $69.7 \%$ had a good or very good perception and $30.3 \%$ a negative perception. Regarding the interrelation of work with family or social problems, $48.4 \%$ said they had a good or very good perception, indicating a lack of conflicts, and 51.6\% made clear the existence of negative conditions. Interpersonal relations at work were good or very good for $66.5 \%$ and harmful for $33.5 \%$.

In Dimension 2 - Work Content, perception about the workload and pace is good or very good for $44.7 \%$ and negative for $55.3 \%$. The work environment is good or very good for $20.2 \%$ and harmful for $79.8 \%$. Work equipment is good or very good for $17 \%$ and harmful for $83 \%$. The 
conception of duties pertaining to the different work positions is good or very good for $25 \%$ while $75 \%$ consider them harmful.

In Dimension 3 - Individual Factors take into account those personal traits acting as buffers for psychological risk. They are good or very good for 76.1\% and negative for 23.9\%. Company characteristics are good or very good for $32.4 \%$ and harmful for $67.6 \%$. Personal characteristics are considered good or very good for $59 \%$ and harmful for $41 \%$.

Regarding Dimension 4 - Psychological wear in as far as health subjective symptoms and alterations and psychological state through a cognitive-emotional response, the results grouped as good or very good are $31.9 \%$ while $68.1 \%$ have shown symptomology. The grouping of behavioral response is good or very good at $66.5 \%$ and harmful at $33.5 \%$. The physiological response is good or very good for $25 \%$ and harmful for $75 \%$.

Table 2. Results by dimensions and factors

\begin{tabular}{ccccccc}
\hline & DIMENSION 1. WORK CONTEXT & \multicolumn{3}{c}{ DIMENSION 3. INDIV. FACT. } \\
\hline D1.F1 & D1.F2 & D1.F3 & D1.F4 & D3.F1 & D3.F2 & D3.F3 \\
CULTURE & ROLE & WORK.FAM. & INTER REL. & BUFFER & COMP.CHAR. & PER.TRAITS \\
Percent & Percent & Percent & Percent & Percent & Percent & Percent \\
5.3 & 11.7 & 6.4 & 25.0 & 23.9 & 7.4 & 8.0 \\
52.1 & 58.0 & 42.0 & 41.5 & 52.2 & 25.0 & 51.0 \\
10.2 & 6.4 & 14.9 & 9.6 & 8.5 & 13.3 & 13.8 \\
32.4 & 23.9 & 34.6 & 20.7 & 15.4 & 47.9 & 22.9 \\
0 & 0 & 2.1 & 3.2 & 0 & 6.4 & 4.3 \\
100.0 & 100.0 & 100.0 & 100.0 & 100.0 & 100.0 & 100.0 \\
& DIMENSION 2. WORK CONTENT & & DIMENSION 4. PSYCH. WEAR \\
\hline D2.F1 & D2.F2 & D2.F3 & D2.F4 & D4.F1 & D4.F2 & D4.F3 \\
LOAD & WORK ENV. EQUIPMENT & DUTIES & COGNI.EMOT. & BEHAVIOR & PHYSIOLOG \\
Percent & Percent & Percent & Percent & Percent & Percent & Percent \\
4.8 & 1.6 & 2.1 & 6.9 & 6.4 & 19.7 & 6.9 \\
39.9 & 18.6 & 14.9 & 18.1 & 25.5 & 46.8 & 18.1 \\
14.3 & 9.1 & 12.8 & 22.3 & 7.5 & 11.7 & 5.3 \\
39.4 & 48.4 & 49.5 & 37.3 & 48.4 & 20.2 & 51.1 \\
1.6 & 22.3 & 20.7 & 15.4 & 12.2 & 1.6 & 18.6 \\
100.0 & 100.0 & 100.0 & 100.0 & 100.0 & 100.0 & 100.0 \\
\hline
\end{tabular}

Source: Results obtained from participants in different business sectors in the State of Hidalgo, México. 2014

While exploring the independent variable, presumably predictors of the psychological wear responses, the results (Table 3), indicate a significant association for the presence of factors: work schedule** and conception of duties pertaining to a work position* for the cognitive-emotional response; the work content dimension**, work environment factors** and conception of duties pertaining to a work position** for the behavioral response; work 
schedule**, the individual factors dimension** and the psychological risk buffers factors $* *$ for the physiological response. The dimensions and factors are not associated with a greater occurrence of the event (the different psychological wear responses). In this case they are considered protection dimensions and factors due to the significant decrease of the risk of psychological wear (in each of the mentioned responses) in the presence of these variables that show $\mathrm{OR}<1$, (IC $<1<1$, $\mathrm{p}=<0.05^{*}$ or $\mathrm{p}=<0.01^{* *}$ ).

The results (Table 3 ) also show a significant association of the work context dimension, the role in the organization factors, the interrelation of work and family or social problems, interpersonal work relations, workload and pace, and company characteristics with the cognitive-emotional response; seniority on the job, the work context and individual factors dimensions, the role in the organization factors, the interrelation of work and family or social problems, interpersonal work relations, psychological risk buffers, company characteristics and personal traits with the behavioral response; training, the work content dimension, the workload and pace factors, work environment, equipment and physical agents, the conception of duties pertaining to a work position and company characteristics with the physiological response. All of these constitute risk factors that may have harmful effects on workers' health.

The variable implying greater risk in triggering psychological wear at the cognitive-emotional level on a general level is Work Context $(p=0.000$ $\operatorname{Exp}(B)=5.565)$, specifically the role in the organization $(p=0.000 \operatorname{Exp}$ $(B)=4.853)$, the interrelation of work and family or social problems $(p=0.000$ $\operatorname{Exp}(B)=3.366)$, interpersonal relations at work $(p=0.007 \operatorname{Exp}(B)=2.649)$, workload and pace $(p=0.024 \operatorname{Exp}(B)=2.040)$, and company characteristics $(p=0.004 \operatorname{Exp}(B)=2.519)$. The variable implying greater risk in triggering psychological wear at the behavioral level on a general level is individual factors $(p=0.000 \operatorname{Exp}(B)=8.531)$, specifically personal traits $(p=0.000 \operatorname{Exp}$ $(B)=6.456)$, as well as the work content dimension $(p=0.000 \operatorname{Exp}(B)=4.759)$, interrelation of work and family or social problems factors $(p=0.000$ Exp $(B)=4.406)$, the role in the organization $(p=0.000 \operatorname{Exp}(B)=4.129)$, psychological risk buffers $(p=0.001$ Exp $(B)=3.048)$, company characteristics $(\mathrm{p}=0.034 \operatorname{Exp}(\mathrm{B})=2.109)$, interpersonal relations at work $(p=0.024 \operatorname{Exp}(B)=2.057)$, and seniority on the job $(p=0.033 \operatorname{Exp}(B)=1.978)$. The psychological wear at the physiological level are: at a general level work content $(p=0.000 \operatorname{Exp}(B)=8.765)$, specifically work environment $(p=0.000$ $\operatorname{Exp}(B)=4.357)$, equipment and physical agents $(p=0.002 \operatorname{Exp}(B)=3.419)$, the conception of duties pertaining to a work position $(p=0.005$ Exp $(B)=2.739)$, workload and pace $(p=0.007 \operatorname{Exp}(B)=2.519)$, training $(p=0.027$ $\operatorname{Exp}(B)=2.111)$, and company characteristics $(\mathrm{p}=0.039 \operatorname{Exp}(\mathrm{B})=2.039)$. The Wald statistic also showed significance results for all the variables. 
Table 3. Contingency Tables

\begin{tabular}{|c|c|c|c|c|c|}
\hline \multirow{2}{*}{$\begin{array}{c}\text { Independent } \\
\text { categorical Variable }\end{array}$} & \multirow{2}{*}{$\begin{array}{l}\text { Chi- } \\
\text { squared }\end{array}$} & \multirow{2}{*}{$\begin{array}{c}\text { "p" value } \\
\text { associated } \\
\text { with contrast }\end{array}$} & \multirow[t]{2}{*}{ OR } & \multicolumn{2}{|c|}{$\begin{array}{l}\text { CI } 95 \% \\
\text { of the OR }\end{array}$} \\
\hline & & & & Inf. & Sup. \\
\hline \multicolumn{6}{|l|}{$\begin{array}{l}\text { COGN. EM. } \\
\text { RESPONSE }\end{array}$} \\
\hline Work schedule & 9.150 & 0.002 & 0.268 & 0.024 & 0.598 \\
\hline Context & 13.710 & 0.000 & 5.565 & 2.076 & 14.920 \\
\hline Role & 14.512 & 0.000 & 4.853 & 2.045 & 11.521 \\
\hline Work family & 14.014 & 0.000 & 3.366 & 1.758 & 6.446 \\
\hline Interper. Rel. & 7.220 & 0.007 & 2.649 & 1.283 & 5.469 \\
\hline Workload and pace & 5.122 & 0.024 & 2.040 & 1.095 & 3.800 \\
\hline Duties & 6.397 & 0.011 & 0.351 & 0.152 & 0.808 \\
\hline \multicolumn{6}{|l|}{$\begin{array}{c}\text { BEHAVIORAL } \\
\text { RESPONSE }\end{array}$} \\
\hline Job Seniority & 4.566 & 0.033 & 1.978 & 1.053 & 3.713 \\
\hline Context & 20.943 & 0.000 & 4.759 & 2.373 & 9.540 \\
\hline Content & 6.975 & 0.008 & 0.385 & 0.187 & 0.793 \\
\hline Indiv. Fact. & 40.990 & 0.000 & 8.531 & 4.245 & 17.146 \\
\hline Role & 18.801 & 0.000 & 4.129 & 2.133 & 7.991 \\
\hline Work family & 20.083 & 0.000 & 4.406 & 2.253 & 8.617 \\
\hline Interper. Rel. & 5.084 & 0.024 & 2.057 & 1.093 & 3.870 \\
\hline Environ. & 10.114 & 0.001 & 0.315 & 0.151 & 0.655 \\
\hline Duties & 16.114 & 0.000 & 0.254 & 0.127 & 0.507 \\
\hline Buffer & 10.433 & 0.001 & 3.048 & 1.526 & 6.086 \\
\hline Company Charact & 4.519 & 0.034 & 2.109 & 1.052 & 4.228 \\
\hline Personal Traits & 32.689 & 0.000 & 6.456 & 3.307 & 12.605 \\
\hline \multicolumn{6}{|l|}{ PHYSIOLOG } \\
\hline Training & 4.874 & 0.027 & 2.111 & 1.080 & 4.125 \\
\hline Work schedule & 14.043 & 0.000 & 0.082 & 0.016 & 0.411 \\
\hline Content & 35.038 & 0.000 & 8.765 & 4.005 & 19.186 \\
\hline Indiv. Fact. & 11.272 & 0.001 & 0.316 & 0.159 & 0.629 \\
\hline Workload and pace & 7.346 & 0.007 & 2.519 & 1.278 & 4.965 \\
\hline Environ. & 15.876 & 0.000 & 4.357 & 2.044 & 9.289 \\
\hline Equipment & 9.842 & 0.002 & 3.419 & 1.543 & 7.577 \\
\hline Duties & 7.953 & 0.005 & 2.739 & 1.340 & 5.595 \\
\hline Buffer & 7.099 & 0.008 & 0.382 & 0.185 & 0.786 \\
\hline Company Charact & 4.279 & 0.039 & 2.039 & 1.031 & 4.033 \\
\hline
\end{tabular}

Source: Results obtained from participants in different business sectors in the State of Hidalgo, México, 2014

A binary logistic regression was made for the multivariate analysis (at the explicative and predictive level) of the independent variables that had shown association with psychological wear (Table 4), confirming that there 
is a causal, harmful or damaging association. When a worker has a negative perception of his or her personal traits as well as the interrelation of work with family or social problems, he or she has a greater risk of psychological wear with behavioral response. Those workers with morning or morning and afternoon work schedule, a bad perception of company characteristics and of the equipment and physical agents, but with a good perception of individual factors, are at greater risk of a physiological response.

Table 4. Bivariate analysis results of binary logistic regression

\begin{tabular}{|c|c|c|c|c|c|c|c|c|c|}
\hline \multirow{2}{*}{$\begin{array}{c}\text { Independent } \\
\text { categorical } \\
\text { Variable }\end{array}$} & \multirow{2}{*}{$\begin{array}{c}\text { Chi- } \\
\text { squared }\end{array}$} & \multirow{2}{*}{$\begin{array}{l}\text { “p” value } \\
\text { associated } \\
\text { with } \\
\text { contrast }\end{array}$} & \multirow[t]{2}{*}{$\begin{array}{c}\text { Coeff. } \\
\text { B }\end{array}$} & \multirow[t]{2}{*}{$\begin{array}{l}\text { Stand } \\
\text { Error }\end{array}$} & \multirow[t]{2}{*}{ Wald } & \multirow{2}{*}{$\begin{array}{l}\text { Sig. } \\
\text { for } \\
\text { gl } 1\end{array}$} & \multirow[t]{2}{*}{ OR } & \multicolumn{2}{|c|}{$\begin{array}{l}\text { CI 95\% } \\
\text { of the OR }\end{array}$} \\
\hline & & & & & & & & Inf. & Sup. \\
\hline \multicolumn{10}{|l|}{$\begin{array}{l}\text { COGN. EM. } \\
\text { RESPONSE }\end{array}$} \\
\hline Work & 9.150 & 0.002 & -1.318 & 0.871 & 2.290 & 0.130 & 0.268 & 0.049 & 1.476 \\
\hline Context & 13.710 & 0.000 & 0.447 & 0.634 & 0.497 & 0.481 & 1.563 & 0.451 & 5.411 \\
\hline Role & 14.512 & 0.000 & 0.585 & 0.545 & 1.153 & 0.283 & 1.795 & 0.617 & 5.221 \\
\hline Work family & 14.014 & 0.000 & 0.727 & 0.384 & 3.583 & 0.058 & 2.068 & 0.975 & 4.389 \\
\hline Interper. Rel. & 7.220 & 0.007 & 0.633 & 0.426 & 2.204 & 0.138 & 1.883 & 0.817 & 4.342 \\
\hline Workloadpace & 5.122 & 0.024 & 0.605 & 0.354 & 2.918 & 0.088 & 1.832 & 0.915 & 3.668 \\
\hline Duties & 6.397 & 0.011 & -0.815 & 0.495 & 2.710 & 0.146 & 0.443 & 0.168 & 1.168 \\
\hline Company & 8.130 & 0.004 & 0.551 & 0.379 & 2.110 & 0.101 & 1.734 & 0.825 & 3.646 \\
\hline \multicolumn{10}{|l|}{ BEHAVIOR } \\
\hline Job Seniority & 4.566 & 0.033 & 0.069 & 0428 & 0.026 & 0.872 & 1.072 & 0.463 & 2.481 \\
\hline Context & 20.943 & 0.000 & 0.140 & 0.567 & 0.061 & 0.805 & 1.150 & 0.379 & 3.492 \\
\hline Content & 6.975 & 0.008 & -0.572 & 0.639 & 0.803 & 0.370 & 0.564 & 0.161 & 1.974 \\
\hline Indiv. Fact. & 40.990 & 0.000 & 1.064 & 0.577 & 3.392 & 0.066 & 2.897 & 0.934 & 8.983 \\
\hline Role & 18.801 & 0.000 & 0.192 & 0.510 & 0.142 & 0.706 & 1.212 & 0.446 & 3.293 \\
\hline Work family & 20.083 & 0.000 & 1.100 & 0.433 & 6.453 & 0.011 & 3.006 & 1.286 & 7.025 \\
\hline Interper. Rel. & 5.084 & 0.024 & 0.239 & 0.426 & 0.315 & 0.574 & 1.270 & 0.552 & 2.924 \\
\hline Environ. & 10.114 & 0.001 & -0.386 & 0.587 & 0.432 & 0.511 & 0.680 & 0.215 & 2.148 \\
\hline Duties & 16.114 & 0.000 & -0.794 & 0.478 & 2.756 & 0.097 & 0.452 & 0.177 & 1.154 \\
\hline Buffer & 10.433 & 0.001 & -0.352 & 0.534 & 0.434 & 0.510 & 0.703 & 0.247 & 2.004 \\
\hline Company & 4.519 & 0.034 & -0.040 & 0.493 & 0.007 & 0.935 & 0.961 & 0.366 & 2.523 \\
\hline $\begin{array}{c}\text { Person. Traits } \\
\text { PHYSIOL }\end{array}$ & 32.689 & 0.000 & 1.187 & 0.477 & 6.192 & 0.013 & 3.276 & 1.287 & 8.340 \\
\hline \multicolumn{10}{|l|}{ RESPONSE } \\
\hline Training & 4.874 & 0.027 & 0.509 & 0.435 & 1.369 & 0.242 & 1.664 & 0.709 & 3.907 \\
\hline Work & 14.043 & 0.000 & -1.899 & 0.952 & 3.980 & 0.046 & 0.150 & 0.023 & 0.967 \\
\hline Content & 35.038 & 0.000 & 0.996 & 0.700 & 2.025 & 0.155 & 2.708 & 0.687 & 10.676 \\
\hline Indiv. Fact. & 11.272 & 0.001 & -1.913 & 0.612 & 9.779 & 0.002 & 0.148 & 0.045 & 0.490 \\
\hline Workloadpace & 7.346 & 0.007 & 0.686 & 0.455 & 2.277 & 0.131 & 1.987 & 0.815 & 4.845 \\
\hline Environ. & 15.876 & 0.000 & -0.034 & 0.670 & 0.003 & 0.959 & 0.966 & 0.260 & 3.591 \\
\hline Equipment & 9.842 & 0.002 & 1.059 & 0.508 & 4.352 & 0.037 & 2.884 & 1.066 & 7.800 \\
\hline Duties & 7.953 & 0.005 & 0.399 & 0.491 & 0.658 & 0.417 & 1.490 & 0.569 & 3.902 \\
\hline Buffer & 7.099 & 0.008 & 0.072 & 0.512 & 0.020 & 0.888 & 1.075 & 0.394 & 2.929 \\
\hline
\end{tabular}


Source: Results obtained from participants in different business sectors in the State of Hidalgo, México, 2014

The results showed that the psychological wear response at the behavioral level has a $94.87 \%$ probability of occurring in workers with a negative perception of their personal traits and of the interrelation of work with family or social problems while in the case of those showing a positive perspective of these factors, the likelihood of manifesting psychological wear with behavioral response is $4 \%$. The probability of showing psychological wear at the physiological level is $97.70 \%$ for those workers with morning or morning and afternoon work schedules, with a good perception of individual factors dealing with their personal traits and psychological wear buffers, and a bad perception of company characteristics and of the equipment and physical agents. But only 5.13\% of workers with work shifts and a good perception of these factors showed psychological wear with physiological response.

Models were tested with the Multivariate Logistic Regression with the step by step method (successive steps), variables were chosen according to the significance criterion (probability of F) and the tolerance criterion, until achieving the most predictive of Psychological Wear at the level of each of the responses (cognitive-emotional, behavioral and physiological). The variables chosen in each case have meaningful partial regression ratios.

The four variables chosen for the final model (role in the organization, interrelation of work with family or social problems, workload and pace, and work schedule) manage to explain $15.60 \%\left(\mathrm{R}^{2}=0.156\right)$ of the variability observed in the cognitive-emotional response (Table 5). The Durbin-Watson statistic with a value of 1.919 proves the assumption that the residuals are independent. ANOVA shows that out of a total of 40.851, 6.373 are explained by regression.

Table 5. Multivariate logistic regression (cognitive-emotional response)

\begin{tabular}{|c|c|c|c|c|c|c|c|c|c|c|c|c|c|c|}
\hline $\begin{array}{l}\text { Psycho. } \\
\text { Wear - } \\
\text { Cogni- } \\
\text { emot. } \\
\text { Resp. }\end{array}$ & $\begin{array}{l}\text { Pear- } \\
\text { son } \\
\text { Correl }\end{array}$ & $\mathrm{R}$ & $\begin{array}{c}\mathrm{R} \\
\text { Square }\end{array}$ & $\begin{array}{l}\text { R Square } \\
\text { corrected }\end{array}$ & $\mathrm{Ee}$ & $\begin{array}{l}\text { Dur } \\
\text { bin- } \\
\text { Wat } \\
\text { son }\end{array}$ & F & B & $\begin{array}{l}\mathrm{Be} \\
\mathrm{ta}\end{array}$ & $\mathrm{T}$ & $\begin{array}{l}\text { CI } \\
\text { lim. } \\
\text { Inf. }\end{array}$ & $\begin{array}{l}\text { CI } \\
\text { lim. } \\
\text { Sup }\end{array}$ & $\begin{array}{l}\text { Stat } \\
\text { coline } \\
\text { Tol- } \\
\text { eran } \\
\text { ce }\end{array}$ & $\begin{array}{l}\text { stic } \\
\text { arity } \\
\text { FIV }\end{array}$ \\
\hline $\begin{array}{l}\text { Model } 1 \\
\text { Const. }\end{array}$ & & .278 & .077 & .072 & .450 & & $15.559 * *$ & .595 & & \multirow{2}{*}{$\begin{array}{c}15.138 \\
3.945 \\
* *\end{array}$} & .518 & .673 & \multirow{3}{*}{1.000} & \multirow{3}{*}{1.000} \\
\hline Role & $.278 * *$ & & & & & & & .282 & .278 & & .141 & .423 & & \\
\hline Model 2 & & .337 & .113 & .104 & .442 & & $\begin{array}{c}11.834 \\
* *\end{array}$ & & & \multirow{3}{*}{$\begin{array}{c}10.908 \\
2.848 \\
* *\end{array}$} & & & & \\
\hline Const. & & & & & & & & .519 & & & .425 & .613 & \multirow[b]{2}{*}{.886} & \multirow[b]{2}{*}{1.129} \\
\hline Role & $.278 * *$ & & & & & & & .212 & .210 & & .065 & .360 & & \\
\hline $\begin{array}{l}\text { Wk. } \\
\text { Fam }\end{array}$ & $.273^{* *}$ & & & & & & & .189 & .202 & $\begin{array}{l}2.750 \\
* *\end{array}$ & .053 & .324 & .886 & 1.129 \\
\hline Model 3 & & .371 & .138 & .124 & .437 & & 9.813 & & & & & & & \\
\hline
\end{tabular}




\begin{tabular}{|c|c|c|c|c|c|c|c|c|c|c|c|c|c|c|}
\hline & & & & & & & $* *$ & & & & & & & \\
\hline Const. & & & & & & & & .439 & & 7.495 & .324 & .555 & & \\
\hline Role & $.278 * *$ & & & & & & & .207 & .204 & $\begin{array}{c}2.802 \\
* *\end{array}$ & .061 & .352 & .885 & 1.130 \\
\hline $\begin{array}{l}\text { Wk. } \\
\text { Fam }\end{array}$ & $.273^{* *}$ & & & & & & & .189 & .203 & $\begin{array}{c}2.791 \\
* *\end{array}$ & .056 & .323 & .886 & 1.129 \\
\hline LoadPac & $.165^{*}$ & & & & & & & .147 & .157 & $\begin{array}{c}2.287 \\
*\end{array}$ & .020 & .274 & .999 & 1.001 \\
\hline Model 4 & & .395 & .156 & .138 & .434 & 1.919 & $\begin{array}{c}8.457 \\
* *\end{array}$ & & & & & & & \\
\hline Const. & & & & & & & & .478 & & 7.791 & .357 & .599 & & \\
\hline Role & $.278^{* *}$ & & & & & & & .194 & .191 & $\begin{array}{c}2.636 \\
* *\end{array}$ & .049 & .339 & .878 & 1.139 \\
\hline $\begin{array}{l}\text { Wk. } \\
\text { Fam }\end{array}$ & $.273^{* *}$ & & & & & & & .170 & .182 & $\begin{array}{c}2.500 \\
*\end{array}$ & .036 & .304 & .868 & 1.153 \\
\hline LoadPac & $.165^{*}$ & & & & & & & .128 & .136 & $\begin{array}{c}1.986 \\
*\end{array}$ & .001 & .255 & .977 & 1.024 \\
\hline $\begin{array}{l}\text { Wk } \\
\text { Sche }\end{array}$ & $-.221^{*}$ & & & & & & & -.303 & -.139 & $-1.980 *$ & -.605 & -.001 & .938 & 1.067 \\
\hline
\end{tabular}

Source: Results obtained from participants in different business sectors in the State of Hidalgo, México, 2014.

The variables chosen for the final model (personal traits, interrelation of work with family or social problems, and conception of the duties of the work position) explain $28.30 \%\left(\mathrm{R}^{2}=0.283\right)$ of the variability observed in the behavioral response (Table 6). The Durbin-Watson statistic with a value of 1.956 proves the assumption that the residuals are independent. ANOVA shows that out of a total of 41.888, 11.850 are explained by regression.

Table 6. Multivariate logistic regression (behavioral response)

\begin{tabular}{|c|c|c|c|c|c|c|c|c|c|c|c|c|c|c|}
\hline $\begin{array}{c}\text { Psycho. Wear } \\
\text { - Behav. } \\
\text { Resp. }\end{array}$ & $\begin{array}{l}\text { Pear- } \\
\text { son } \\
\text { Correl }\end{array}$ & $\mathrm{R}$ & $\begin{array}{c}\mathrm{R} \\
\text { Square }\end{array}$ & $\begin{array}{l}\text { R Square } \\
\text { corrected }\end{array}$ & $\mathrm{Ee}$ & $\begin{array}{l}\text { Dur } \\
\text { bin- } \\
\text { Wat } \\
\text { son }\end{array}$ & F & B & $\begin{array}{l}\mathrm{Be} \\
\text { ta }\end{array}$ & $\mathrm{T}$ & $\begin{array}{l}\text { CI } \\
\lim . \\
\text { Inf. }\end{array}$ & $\begin{array}{l}\text { CI } \\
\lim . \\
\text { Sup }\end{array}$ & $\begin{array}{l}\text { Stati } \\
\text { coline } \\
\text { Toleran } \\
\text { ce }\end{array}$ & $\begin{array}{l}\text { tic } \\
\text { arity } \\
\text { FIV }\end{array}$ \\
\hline Model 1 & & .417 & .174 & .169 & .431 & & $39.148 * *$ & & & & & & & \\
\hline Const. & & & & & & & & .171 & & 4.181 & .090 & .252 & & \\
\hline $\begin{array}{l}\text { Personal } \\
\text { Traits }\end{array}$ & $.417 * *$ & & & & & & & .400 & .417 & $\begin{array}{c}6.257 \\
* *\end{array}$ & .274 & .526 & 1.000 & 1.000 \\
\hline Model 2 & & .481 & .232 & .223 & .417 & & $\begin{array}{c}27.872 \\
* *\end{array}$ & & & & & & & \\
\hline Const. & & & & & & & & .073 & & 1.526 & -.021 & .167 & & \\
\hline $\begin{array}{l}\text { Personal } \\
\text { Traits }\end{array}$ & $.417 * *$ & & & & & & & .348 & .362 & $\begin{array}{c}5.480 \\
* *\end{array}$ & .223 & .473 & .951 & 1.052 \\
\hline Wk. Fam & $.327 * *$ & & & & & & & .233 & .246 & $\begin{array}{c}3.726 \\
* *\end{array}$ & .109 & .356 & .951 & 1.052 \\
\hline Model 3 & & .532 & .283 & .271 & .404 & 1.956 & $\begin{array}{c}24.195 \\
* *\end{array}$ & & & & & & & \\
\hline Const. & & & & & & & & .276 & & 3.805 & .133 & .420 & & \\
\hline $\begin{array}{l}\text { Personal } \\
\text { Traits }\end{array}$ & $.417 * *$ & & & & & & & .318 & .331 & $\begin{array}{c}5.128 \\
* *\end{array}$ & .196 & .440 & .934 & 1.071 \\
\hline Wk. Fam & $.327 * *$ & & & & & & & .225 & .238 & $\begin{array}{c}3.710 \\
* *\end{array}$ & .105 & .344 & .949 & 1.053 \\
\hline Duties & $\begin{array}{c}- \\
.293 * *\end{array}$ & & & & & & & -.250 & -.229 & $\begin{array}{c}-3.630 \\
* *\end{array}$ & -.386 & -.114 & .978 & 1.022 \\
\hline
\end{tabular}

$* \mathrm{p}<.05-* * \mathrm{p}<.01$

Source: Results obtained from participants in different business sectors in the State of Hidalgo, México, 2014. 
Lastly, the variables chosen for the final model (work environment, work schedule, equipment and physical agents, and workload and pace) explain $20.60 \%\left(\mathrm{R}^{2}=0.206\right)$ of the variability observed in the physiological response (Table 7). The Durbin-Watson statistic with a value of 1.686 proves the assumption that the residuals are independent. ANOVA shows that out of a total of 35.250, 7.258 are explained by regression.

Table 7. Multivariate logistic regression (physiological response)

\begin{tabular}{|c|c|c|c|c|c|c|c|c|c|c|c|c|c|c|}
\hline $\begin{array}{c}\text { Psycho. } \\
\text { Wear - } \\
\text { Physio. } \\
\text { Resp. }\end{array}$ & $\begin{array}{l}\text { Pear- } \\
\text { son } \\
\text { Corre } \\
\text { l }\end{array}$ & $\mathrm{R}$ & $\begin{array}{c}\mathrm{R} \\
\text { Squar } \\
\mathrm{e}\end{array}$ & $\begin{array}{c}\mathrm{R} \\
\text { Square } \\
\text { correcte } \\
\mathrm{d}\end{array}$ & $\mathrm{Ee}$ & $\begin{array}{l}\text { Dur } \\
\text { bin- } \\
\text { Wat } \\
\text { son }\end{array}$ & $\mathrm{F}$ & B & $\begin{array}{l}\mathrm{Be} \\
\text { ta }\end{array}$ & $\mathrm{T}$ & $\begin{array}{c}\text { CI } \\
\text { lim. } \\
\text { Inf. }\end{array}$ & $\begin{array}{l}\text { CI } \\
\text { lim. } \\
\text { Sup }\end{array}$ & $\begin{array}{c}\text { Stati } \\
\text { coline } \\
\text { Tolera } \\
\text { n } \\
\text { ce }\end{array}$ & $\begin{array}{l}\text { tic } \\
\text { arity } \\
\text { FIV }\end{array}$ \\
\hline $\begin{array}{c}\text { Model } \\
1\end{array}$ & & $\begin{array}{c}.29 \\
1\end{array}$ & .084 & .080 & $\begin{array}{c}.41 \\
7\end{array}$ & & $\begin{array}{c}17.155^{*} \\
*\end{array}$ & & & & & & & \\
\hline Const. & & & & & & & & .500 & & 7.399 & .367 & .633 & & \\
\hline Eviron. & $\begin{array}{c}.291 * \\
*\end{array}$ & & & & & & & .313 & .291 & $\begin{array}{c}4.142 \\
* *\end{array}$ & .164 & .463 & 1.000 & $\begin{array}{c}1.00 \\
0\end{array}$ \\
\hline $\begin{array}{c}\text { Modelo } \\
2\end{array}$ & & $\begin{array}{c}.38 \\
5\end{array}$ & .148 & .139 & $\begin{array}{c}.40 \\
3\end{array}$ & & $\begin{array}{c}16.106 \\
* *\end{array}$ & & & & & & & \\
\hline Const. & & & & & & & & .541 & & 8.159 & .410 & .671 & & \\
\hline $\begin{array}{c}\text { Environ } \\
.\end{array}$ & $\begin{array}{c}.291 * \\
*\end{array}$ & & & & & & & .293 & .272 & $\begin{array}{c}3.998 \\
* *\end{array}$ & .149 & .438 & .995 & $\begin{array}{c}1.00 \\
5\end{array}$ \\
\hline $\begin{array}{l}\text { Wk } \\
\text { Sche }\end{array}$ & $\begin{array}{c}- \\
.273^{*} \\
*\end{array}$ & & & & & & &. & $\begin{array}{c}- \\
.253\end{array}$ & $\begin{array}{c}- \\
3.724 \\
* *\end{array}$ & $\begin{array}{c}- \\
.786\end{array}$ &. & .995 & $\begin{array}{c}1.00 \\
5\end{array}$ \\
\hline $\begin{array}{c}\text { Model } \\
\mathbf{3}\end{array}$ & & $\begin{array}{c}.43 \\
3\end{array}$ & .187 & .174 & $\begin{array}{c}.39 \\
5\end{array}$ & & $\begin{array}{c}14.119 \\
* *\end{array}$ & & & & & & & \\
\hline Const. & & & & & & & & .378 & & 4.460 & .211 & .546 & & \\
\hline $\begin{array}{c}\text { Environ } \\
.\end{array}$ & $\begin{array}{c}.291 * \\
*\end{array}$ & & & & & & & .258 & .239 & $\begin{array}{c}3.545 \\
* *\end{array}$ & .114 & .402 & .968 & $\begin{array}{c}1.03 \\
3\end{array}$ \\
\hline $\begin{array}{l}\text { Wk } \\
\text { Sche }\end{array}$ & $\begin{array}{c}- \\
.273^{*} \\
*\end{array}$ & & & & & & & $\begin{array}{c}- \\
.533\end{array}$ & $\begin{array}{c}- \\
.263\end{array}$ & $\begin{array}{c}- \\
3.939 \\
* *\end{array}$ & $\begin{array}{c}- \\
.800\end{array}$ & $\begin{array}{c}- \\
.266\end{array}$ & .992 & $\begin{array}{c}1.00 \\
8\end{array}$ \\
\hline $\begin{array}{c}\text { Equipm } \\
\mathrm{t}\end{array}$ & $\begin{array}{c}.229 * \\
*\end{array}$ & & & & & & & .230 & .200 & $\begin{array}{c}2.964 \\
* *\end{array}$ & .077 & .383 & .972 & $\begin{array}{c}1.02 \\
9\end{array}$ \\
\hline $\begin{array}{c}\text { Model } \\
4\end{array}$ & & $\begin{array}{c}.45 \\
4\end{array}$ & .206 & .189 & $\begin{array}{c}.39 \\
1\end{array}$ & $\begin{array}{c}1.68 \\
6\end{array}$ & $\begin{array}{c}11.863 \\
* *\end{array}$ & & & & & & & \\
\hline Const. & & & & & & & & .320 & & 3.601 & .144 & .495 & & \\
\hline $\begin{array}{c}\text { Environ } \\
.\end{array}$ & $\begin{array}{c}.291^{*} \\
*\end{array}$ & & & & & & & .248 & .230 & $\begin{array}{c}3.428 \\
* *\end{array}$ & .105 & .391 & .964 & $\begin{array}{c}1.03 \\
7\end{array}$ \\
\hline $\begin{array}{l}\text { Wk } \\
\text { Sche }\end{array}$ & $\begin{array}{c}- \\
.273^{*} \\
*\end{array}$ & & & & & & & $\begin{array}{c}- \\
.492\end{array}$ & $\begin{array}{c}- \\
.243\end{array}$ & $\begin{array}{c}- \\
3.631 \\
* *\end{array}$ & $\begin{array}{c}- \\
.760\end{array}$ & $\begin{array}{c}- \\
.225\end{array}$ & .972 & $\begin{array}{c}1.02 \\
9\end{array}$ \\
\hline$\underset{t}{\text { Equipm }}$ & $\begin{array}{c}.229 * \\
*\end{array}$ & & & & & & & .228 & .198 & $\begin{array}{c}2.961 \\
* *\end{array}$ & .076 & .380 & .972 & $\begin{array}{c}1.02 \\
9\end{array}$ \\
\hline $\begin{array}{l}\text { LoadPa } \\
\text { c }\end{array}$ & $.198 *$ & & & & & & & .121 & .139 & $\begin{array}{c}2.081 \\
*\end{array}$ & .006 & .236 & .973 & $\begin{array}{c}1.02 \\
8\end{array}$ \\
\hline
\end{tabular}

\section{Discussion}

Different investigations coincide in considering that perception of harmful psychosocial factors related to Work Context and Content show a strong association with the probability of causing psychological wear, and conclude that said factors and the perceptions held about them may affect health (Lopez-Baron and Carrion-Garcia, 2006; Rotenberg, 2004; Dejours, 
2008; Londoño et al, 2010). This coincides with the results obtained where "work context" is the variable, implying a greater risk for triggering psychological wear at the cognitive-emotional level. It also triggers psychological wear at the behavioral level, although this is second in importance after "individual factors". The variable implying the greatest risk of psychological wear at the physiological level is "work content".

The importance of a healthy work environment, as also seen in the WHO guidelines (2010), fosters positive psychosocial factors for promoting health among workers as postulated by Moreno and Baez (2010), is obvious when we prove that some of the variables of this study become protection factors due to a significant reduction of psychological wear.

Letelier, Navarrete and Farfan (2014) observed that as workers rack up more seniority at the company, burnout ratios increase. They even mention an accelerated presence of ratios and symptoms in those who have been working for more than five years. An increased possibility of occurrence in younger motivated people with little work experience is also observed. The results of this study differ in that neither seniority nor age showed association with psychological wear.

A worker's perception of his or her personal traits and the interrelation of work with family or social problems play a crucial role in the response at the behavioral level; if said perception is positive, the likelihood of having psychological wear with a behavioral response is very small (4\%). On the other hand, if it is negative, there is a high likelihood of occurrence of psychological wear at the behavioral level, almost 95\%. For workers with a morning or morning and afternoon work schedule and a good perception of individual factors such as personal traits and psychological wear buffers but at the same time a bad perception of company characteristics and of the equipment and physical agents, the probability of displaying psychological wear at the physiological level is practically $98 \%$.

The results of this investigation differ largely from a recent study using the same instrument (Carrion-Garcia, Gutierrez-Strauss and LopezBaron, 2014), that showed worse results regarding psychological wear in subjective health symptoms and alterations and psychological state in each of the different responses.

\section{Conclusion}

The instrument's confidence should be reviewed with a larger sample of Mexican population to corroborate if the Cronbach Alfa is shown to be low in any of the dimensions and, therefore, with a limited correlation between the items in the sample from the State of Hidalgo, suggesting a modification of the instrument or if its initial confidence is maintained. The 
battery validation must undergo a continuous review process to be able to make any pertinent modifications based on the investigations made.

The results of the analysis show the significance of the psychosocial factors of Work Context, Work Content and Individual Factors and their positive association with psychological wear. The factors dealing with work context (role in the organization, the interrelation of work with family or social problems) and with work content (workload and pace) are associated with the cognitive-emotional response. Furthermore, individual factors (personal traits) and work context (the interrelation of work with family or social problems) are associated with the behavioral response. Work content (work environment, equipment and physical agents, and workload and pace) are associated with the physiological response.

The work schedule and the conception of duties pertaining to the work position are considered to be protective factors against psychological wear in the cognitive-emotional response as are work content, work environment and the conception of duties pertaining to the work position for the behavioral response and work schedule, individual factors and psychological risk buffers for the physiological response.

These results show greater evidence for determining the psychosocial factors associated with workers' health and provide knowledge about the different responses to psychological wear that may occur, thus facilitating intervention actions.

\section{References:}

Blanch JM, Sahagún M, Cervantes G (2010): Factor Structure of Working Conditions Questionnaire. Revista de Psicología del Trabajo y de las Organizaciones, 26 (3), 175-189.

Carrasco González AM, de la Corte CM, León Rubio JM. (2010): Engagement: Un recurso para optimizar la salud psicosocial en las organizaciones y prevenir el burnout y estrés laboral. Revista Digital de Prevención 28 de abril. 1

Carrión-García, MÁ. Modelo de intervención integral en Salud Ocupacional: Modelo de Gestión Psicosocial AEPA. Libro de Actas III Encuentro Nacional y I Internacional sobre Prevención y Salud Laboral. Universidad Politécnica de Catalunya. Edited by ITPF-MAC; 2003.

Carrión-García MÁ, López-Barón F. Elementos para un programa de salud mental en la empresa. En Varillas W (comp.). Los trabajadores y la salud mental. El reto de la prevención y el tratamiento en un mundo enfermo. Red Iberoamericana de Riesgos Psicosociales Laborales. Editorial Ciencias Médicas. Havana. 2009. p. 63.

Carrión-García, MÁ. (2010) Gestión para una empresa saludable: ganamos todos. Artículo en Aldrete, G. y Contreras, M.: Educación para la Salud 
Ocupacional II: metodologías y prácticas. Universidad de Guadalajara. Centro Universitario de Ciencias de la Salud. Ed. Página Seis, S.A. Guadalajara (México). ISBN 978-607-7768-16-6.

At http:/hdl.handle.net/10609/38921

Carrión-García MÁ. La valoración del daño psicosocial: factores psicosociales laborales y efectos sobre la salud. Saarbrucken: Editorial Académica Española. October 2013

Carrión-García M.Á. (2014): CTCPS-MAC: Batería para el estudio de las condiciones de trabajo de carácter psicosocial. Saarbrucken: Editorial Académica Española.

Carrión-García MÁ., Gutiérrez-Strauss AM, López-Barón F. Condiciones de trabajo psicosociales y desgaste psíquico en trabajadores de diversos sectores empresariales de Centro Oriente, Suroccidente y Región Caribe en Colombia. Revista científica Salud Uninorte. 2014; 30 (3): 323-331.

Carrión-Garcia MÁ, López-Barón F, Gutiérrez-Strauss AM. Influencia de factores negativos del Contexto de trabajo en desgaste psíquico de trabajadores en Colombia. Hacia la promoción de la salud. Edit. Universidad de Caldas. Vicerrectoría de Investigaciones y Postgrados. Colombia, 2015 (being prepared)

Cox T, Griffiths AJ, Rial-González E. Research on work-related stress. European Agency for Workplace Safety and health. Luxemburg: Office of Official European Union Publications, 2000.

Dejours C. Locura del trabajo: un estudio de la psicopatología del trabajo (5 $5^{a}$ ed.). Sao Paulo: Cortez-Obore; 1992. Cited in Vasconcelos A, Faria JH. (2008). Saúde mental no trabalho: contradições e límites. Psicologia \& Sociedade, 20(3), 453-464. Retrieved July 11, 2014, available at: http://www.scielo.br/scielo.php?script=sci_arttext\&pid=S0102-

$71822008000300016 \& \operatorname{lng}=$ en\&tlng=pt.

10.1590/S0102-

71822008000300016

Deligkaris P, Panagopoulou E, Montgomery AJ, Masoura E. Job burnout and cognitive functioning: A systematic review. Work Stress. 2014; 28 (2):107123.

Díaz DL. Estrés laboral y sus factores de riesgo psicosocial. CES Salud Pública, 2011; 2(1): 80-84.

Díez M y Dolan S (2008): Burnout vs. Vigor profesional: Análisis configuracional de las características sociolaborales e individuales protectoras en médicos catalanes. Revista de Psiquiatría del Uruguay, 72 (2), 169-185.

Gil-Monte PR. Burnout síndrome ¿síndrome de quemarse por el trabajo, desgaste profesional, estrés laboral o enfermedad de Tomás? Revista de Psicología del Trabajo y de las Organizaciones. 2003; 19 (2):1811-97. 
Hernández R, Fernández C, Baptista P. Metodología de la investigación. $5^{\text {a }}$ ed. México: D.F: McGraw-Hill Interamericana; 2010

Holten AL, Gensby U, Nielsen K. (2008): Strategier for virksomheders forebyggende indsats til forbedring af det psykosociale arbejdsmiljø eksempler fra Norge, Spanien og Polen. Det Nationale Forskningscenter for Arbejdsmiljø, København. Available at http://www.arbejdsmiljoforskning.dk/upload/rapporter/rapport_nor-spapol.pdf

Instituto Nacional de Seguridad e Higiene en el Trabajo. (2008): Evaluación de riesgos ergonómicos y psicosociales. En ERGA-Noticias. 105: 2.

Instituto Nacional de Seguridad e Higiene en el Trabajo. F-PSICO. Factores psicosociales. Método de evaluación. Versión 3.1; 2014.

Knifton L, Watson V, Gründemann R, Dijkman A, den Besten H, ten Have D. Guidelines for Businessmen. How to promote mental health at work. ENWHP. 2011.

Letelier G, Navarrete E, Farfán C. (2014): Síndromes organizacionales: mobbing y burnout. Revista Iberoamericana de Ciencias. 1 (1): 29-40.

Londoño NH, Marín CA, Juárez F, Palacio J, Muñiz O, Escobar B, et al. Factores de riesgo psicosociales y ambientales asociados a trastornos mentales. Suma Psicológica, 2010, 17(1), 59-68. Retrieved July 11, 2014, Available at: http://www.scielo.org.co/scielo.php?script=sci_arttext\&pid=S012143812010000100005\&lng=en\&tlng=es López-Barón F, Carrión-García MÁ. Perspectiva organizacional de los factores psicosociales. En Arellano, G (coord.). Factores psicosociales en el trabajo, un enfoque multidisciplinario. Universidad Autónoma de Aguascalientes. México; 2006.

López-Barón F, Martínez-Alcántara S. El proceso de intervención psicosocial: presentación del proyecto y el convenio con la empresa / organización. En Pando, Román y Acosta (Comp.). Factores psicosociales de riesgo de trabajo en la empresa. Red Iberoamericana de Riesgos Psicosociales Laborales. Havana, Cuba; 2008.

López-Barón F, Carrión-García MÁ El acoso psicológico en el trabajo. Conocerlo para identificar y mejorar las condiciones de trabajo. En Varillas W (comp.). Los trabajadores y la salud mental. El reto de la prevención y el tratamiento en un mundo enfermo. Red Iberoamericana de Riesgos Psicosociales Laborales. Editorial Ciencias Médicas. Havana, 2009. p. 25.

Mababu R. El constructo de trabajo emocional y su relación con el síndrome de desgaste profesional. International Journal of Psychology and Psychological Therapy. 2012; 12 (2):219-224. 
Moreno B, Báez C. Factores y riesgos psicosociales, formas, consecuencias, medidas y buenas prácticas. Madrid: Universidad Autónoma de Madrid. Instituto Nacional de Seguridad e Higiene en el Trabajo INSHT; 2010.

Moreno-Jiménez B, González JL, Garrosa E. Desgaste profesional (burnout), personalidad y salud percibida. En Buendía J y Ramos F (Ed.). Empleo, estrés y salud. Pirámide. Madrid; 2001. 59-83.

Pando Moreno M, Salazar Estrada JG. (2007): Calidad de vida en el trabajo y la salud mental positiva. En Carrión-García Á, López-Barón F, Tous J (Dirs). Evaluación e intervención psicosocial. Asociación de Expertos en Psicosociología Aplicada - AEPA. Mollet del Valles. 81-109.

Real Academia Española. Desgaste. En Diccionario de la lengua española (22.a ed.). 2001a. Retrieved from http://lema.rae.es/drae/?val=desgaste Real Academia Española. Desgastar. En Diccionario de la lengua española (22.a ed.). 2001b. Recuperado de http://lema.rae.es/drae/?val=desgastar Real Academia Española. Psíquico. En Diccionario de la lengua española (22.a ed.). 2001c. Retrieved from http://lema.rae.es/drae/?val=ps\%C3\%ADquico

Rodríguez Carvajal R, de Rivas Hermosilla S. Los procesos de estrés laboral y desgaste profesional (Burnout): diferenciación, actualización y línea de intervención. Med Seg Trabajo. 2011. 57 (1):72-88

Rotenberg L. Fórum: horários de trabalho e saúde. Cad. Saúde Pública [serial on the Internet]. 2004 Dec [cited 2014 July 11]; 20(6): 1730-1731. Available at: http://dx.doi.org/10.1590/S0102-311X2004000600032.

Salanova M. Organizaciones saludables: Una aproximación desde la psicología positiva. En Vázquez C., y Hervás G (Eds): Psicología positiva: Bases científicas del bienestar y la resilencia. Madrid. Alianza Editorial. 2008

Saldaña Orozco C, Ramírez Lira E, Anaya Velasco A, Baeza Alcaraz M. Evaluación de los riesgos psicosociales con el instrumento "CTCPS-MAC" Batería para el estudio de las condiciones de trabajo de carácter psicosocial en el departamento de obras públicas de un Ayuntamiento del sur de Jalisco. Revista científica Salud Uninorte. 2014; 30 (3).

Tucker MK, Jimmieson NL, Oei TP. (2013): The relevance of shared experiences: A multi-level study of collective efficacy as a moderator of job control in the stressor-wear relationship. Work \& Stress, 27 (1), 1-21.

Vázquez C. La psicología positiva en perspectiva. Papeles del Psicólogo, 2006; 27(1): 1-2 Available at: http://www.cop.es/papeles

Vera B. Psicología positiva: una nueva forma de entender la psicología. Papeles del Psicólogo, 2006; 27(1): 3-8 Available at: http://www.cop.es/papeles 
World Health Organization. Healthy Work Environment: OMS Guidelines and Models. Contextualization, practices and supporting literature. 2010. p. 14

World Health Organization. Definition of Mental health. Retrieved from http://www.who.int/features/factfiles/mental_health/es/ 